\title{
STRES PADA TENAGA KESEHATAN SAAT PANDEMI COVID-19: TINJAUAN LITERATUR
}

\author{
Shenna Mentari Ayuningtyas ${ }^{1}$ Wiwin Hendriani ${ }^{2}$ \\ Email: shenna.mentari.ayuningtyas-2020@psikologi.unair.ac.id ${ }^{l}$ \\ Fakultas Psikologi Universitas Airlangga Surabaya ${ }^{1,2}$
}

\begin{abstract}
Abstrak
Sejak dideklarasikannya COVID-19 sebagai pandemi oleh WHO, tenaga kesehatan sebagai profesi yang memiliki peran yang signifikan terhadap penanganan pandemi, lebih berisiko untuk mengalami stres dibandingkan profesi lain. Tujuan studi ini adalah untuk memperoleh fakta terkait stres pada tenaga kesehatan di masa pandemi COVID-19. Pencarian basis data elektronik melalui Google Scholar, Springer Link, Sage Journals, Science Direct, dan basis data WHO dilakukan untuk mengidentifikasi penelitian tentang stres pada tenaga kesehatan saat menghadapi pandemi COVID-19 yang dirilis sejak tahun 2019 yang merupakan awal teridentifikasinya COVID-19 di Wuhan, Cina. Lima penelitian diperoleh berdasarkan kriteria inklusif dan eksklusif pada tinjauan literatur ini. Kelima penelitian menggunakan desain penelitian kualitatif dan kuantitatif. Berdasarkan kelima penelitian tersebut, tenaga kesehatan menunjukkan tingkat stres ringan hingga berat saat menghadapi pandemi COVID-19 yang disebabkan oleh faktor sosiodemografis, kondisi personal, tuntutan organisasi, dan dukungan sosial.
\end{abstract}

Kata Kunci: Stres, Tenaga Kesehatan, Pandemi

\section{Abstract}

Since the declaration of COVID-19 as pandemic by WHO, health workers, as a profession that has a significant role in handling pandemic, are more at risk of experiencing stress compared to other profession. The aim of this study is to obtain facts related to stress in health workers during the COVID-19 pandemic. Electronic database searches through Google Scholar, Springer Link, Sage Journals, Science Direct, and the WHO database were carried out to identify researches about stress in health workers during the COVID-19 pandemic released since 2019 which was the beginning of the identification of COVID-19 in Wuhan, China. Five studies were obtained based on the inclusive and exclusive criteria in this literature review. The five studies used qualitative and quantitative research designs. Based on these five studies, health workers show mild to severe stress level when facing the COVID-19 pandemic which is caused by socio-demographic, personal conditions, organizational demands, and social support.

Keywords: Stress, Health Workers, Pandemic

\section{PENDAHULUAN}

Corona virus disease 2019, atau yang disebut sebagai COVID-19, merupakan penyakit menular yang teridentifikasi sebagai klaster pneumonia. Penyakit ini disebabkan oleh virus corona baru yang kemudian disebut sebagai SARS-CoV-2. COVID-19 awalnya menyebar secara lokal di Wuhan, Cina. COVID-19 kemudian menyebar dengan cepat ke seluruh dunia dan menjadi ancaman kesehatan yang serius. Tingkat penyebaran dan keparahan yang tinggi menyebabkan World Health Organization (WHO) mendeklarasikan COVID-19 sebagai pandemi. Hingga tanggal 2 November 2020, kasus positif COVID-19 yang terkonfirmasi di seluruh dunia telah mencapai 46.403.652 kasus, kematian 1.198.569, dan telah menjangkit 219 negara (WHO, 2020). 
Tren COVID-19 dunia yang terus meningkat (WHO, 2020) menimbulkan tantangan pekerjaan yang semakin besar bagi tenaga kesehatan, seperti bertambahnya beban kerja, keharusan pemakaian alat pelindung diri (APD) dalam waktu yang lama, risiko paparan virus yang tinggi, dan keterbatasanketerbatasan lain dalam menghadapi situasi baru. Tantangan pekerjaan yang besar menyebabkan tenaga kesehatan rentan mengalami gangguan psikologis. Beberapa penelitian telah dilakukan di berbagai negara untuk melihat gangguan psikologis pada tenaga kesehatan di masa pandemi COVID-19. Gangguan psikologis yang muncul berupa kecemasan, depresi, masalah tidur, dan/atau distres/stres (Muller, et al., 2020).

Tenaga kesehatan, sebagai profesi yang memiliki peran yang signifikan terhadap penanganan pandemi, lebih berisiko untuk mengalami stres. Tenaga kesehatan menunjukkan tingkat stres yang lebih tinggi daripada masyarakat umum (Chen, et al., 2020). Rehman, et al. (2020) dalam penelitiannya menjelaskan bahwa selain siswa, tenaga kesehatan menunjukkan tingkat stres, kecemasan, dan depresi yang lebih tinggi dibandingkan profesi lainnya. Lebih lanjut da Silva dan Neto (2020) menjelaskan gangguan psikiatri, salah satunya distres, pada tenaga kesehatan lebih parah dari profesi lain.

Stres, sebagai salah satu gangguan psikologis yang muncul pada tenaga kesehatan, merupakan respon individu terhadap tekanan. Lebih lanjut Hendriani (2020) menjelaskan bahwa stres merupakan respon normal saat individu menghadapi situasi yang menyebabkan ketidakseimbangan dalam diri individu. Stres terjadi apabila individu menilai situasi sebagai ancaman yang lebih besar daripada kemampuan koping yang ia miliki (Hendriani, 2019).

Berdasarkan penjelasan di atas, stres adalah respon normal individu saat menghadapi ancaman yang lebih besar daripada kemampuan koping yang dimiliki, sehingga menimbulkan ketidakseimbangan dalam diri individu. Tinjauan sistematis ini bertujuan untuk mengetahui fakta terkait stres pada tenaga kesehatan di masa pandemi COVID-19.

\section{METODE PENELITIAN}

Tinjauan sistematis ini lakukan dengan pencarian sumber-sumber melalui basis data elektronik dilakukan mulai bulan Oktober 2020. Sumber-sumber yang diambil ialah jurnal penelitian yang dirilis sejak tahun 2019 yang merupakan awal teridentifikasinya COVID-19 di Wuhan, Cina, dapat diunduh secara lengkap, dan 
memberikan informasi relevan terkait stres pada tenaga kesehatan saat pandemi COVID-19.

Mesin pencarian yang digunakan dalam tinjauan sistematis ini adalah Google Scholar, Springer Link, Sage Journals, Science Direct, dan basis data WHO. Kata kunci yang digunakan untuk mencari jurnal-jurnal penelitian yang relevan adalah "stress"; "stress level"; "stress related factor"; "health workers"; "healthcare workers"; "healthcare professional"; "doctor"; "pandemic"; "covid"; "COVID-19"; "stress among health workers qualitative"; "stress among health workers quantitative". Abstrak yang tidak memuat informasi yang relevan tetap ditinjau kembali untuk mengetahui ketersediaan informasi yang masih dapat digunakan untuk pembahasan tinjauan sistematis ini.

Kriteria inklusif pada studi ini adalah penelitian yang memuat tingkat dan faktor-faktor yang berkaitan dengan stres pada tenaga kesehatan di masa pandemi COVID-19. Partisipan penelitian tidak terbatas usia dan jenis kelamin. Metode penelitian pada artikel yang digunakan adalah kualitatif dan kuantitatif. Kriteria eksklusif pada studi ini adalah penelitian yang memuat pengalaman psikologis tenaga kesehatan secara umum, penelitian dengan partisipan selain tenaga kesehatan, dan penelitian dengan bahasa Jerman.

\section{HASIL DAN PEMBAHASAN}

Setelah melakukan pencarian melalui basis data dan melalui proses inklusi dan eksklusi, diperoleh lima penelitian yang digunakan dalam studi ini. Penelitian-penelitian tersebut dilakukan di luar Indonesia dengan jumlah partisipan paling sedikit 18 orang dan paling banyak 1208 orang. Penelitian dilakukan pada tahun 2020 mengingat identifikasi pertama kasus COVID-19 dilakukan pada bulan Desember 2019 dan dideklarasikannya COVID-19 sebagai pandemi oleh WHO pada tahun 2020. Satu penelitian menggunakan metode kualitatif, sedangkan empat lainnya menggunakan metode kuantitatif crosssectional. Sampel terdiri dari perempuan dan laki-laki yang berprofesi sebagai tenaga medis yang terlibat dalam penanganan COVID-19, yaitu dokter, perawat, tenaga medis pendukung, dan tenaga non klinis. Secara keseluruhan, sampel mengalami stres dengan tingkat yang ringan hingga berat. Rangkuman stres yang muncul pada tenaga kesehatan dan faktor-faktor yang berkaitan ada pada Tabel 1 dan Tabel 2 
Tabel 1. Rangkuman Stres yang Muncul pada Tenaga Kesehatan

\begin{tabular}{|c|c|c|c|c|}
\hline $\begin{array}{l}\text { Penulis } \\
\text { \& Tahun }\end{array}$ & Tujuan Penelitian & $\begin{array}{c}\text { Desain } \\
\text { Penelitian }\end{array}$ & $\begin{array}{l}\text { Sampel \& Lokasi } \\
\text { Penelitian }\end{array}$ & Hasil Penelitian \\
\hline $\begin{array}{l}\text { Dobson, } \\
\text { et al., } \\
2020\end{array}$ & $\begin{array}{l}\text { Menguji distres } \\
\text { psikologis pada tenaga } \\
\text { kesehatan saat pandemi } \\
\text { COVID-19 pada bulan } \\
\text { April-Mei 2020 }\end{array}$ & $\begin{array}{l}\text { Studi } \\
\text { kuantitatif } \\
\text { cross- } \\
\text { sectional }\end{array}$ & $\begin{array}{l}320 \text { orang tenaga } \\
\text { kesehatan di rumah } \\
\text { sakit tersier di } \\
\text { Melbourne, } \\
\text { Australia. }\end{array}$ & $\begin{array}{l}\text { Adanya distres dengan tingkat } \\
\text { sedang hingga tinggi yang } \\
\text { ditunjukkan } \\
\text { munculnya gejala sedang } \\
\text { hingga berat pada depresi } \\
(21 \%) \text {, kecemasan }(20 \%) \text {, dan } \\
\text { posttraumatic stress disorders } \\
\text { (PTSD; 29\%). }\end{array}$ \\
\hline $\begin{array}{l}\text { Alizadeh, } \\
\text { et al., } \\
2020\end{array}$ & $\begin{array}{l}\text { Meguji distres } \\
\text { psikologis yang dialami } \\
\text { oleh tenaga Kesehatan } \\
\text { Iran di beberapa pekan- } \\
\text { pekan awal munculnya } \\
\text { COVID-19 }\end{array}$ & $\begin{array}{l}\text { Studi } \\
\text { kualitatif }\end{array}$ & $\begin{array}{lr}18 \text { orang } & \text { tenaga } \\
\text { kesehatan } & \text { yang } \\
\text { menangani } & \text { pasien } \\
\text { COVID-19 } & \text { di } \\
\text { rumah sakit rujukan } \\
\text { di Iran. }\end{array}$ & $\begin{array}{l}\text { Penelitian ini menjelaskan } \\
\text { adanya stres yang muncul } \\
\text { pada situasi terkait tuntutan } \\
\text { pekerjaan dan sumber daya } \\
\text { pendukung. }\end{array}$ \\
\hline
\end{tabular}

Wang et Menguji stres dan Studi 1208 orang tenaga Kurang dari 60\% partisipan al., 2020 faktor yang kuantititati kesehatan yang memiliki tingkat stres sedang mempengaruhi stres f menangani pasien hingga berat, atau tergolong pada tenaga kesehatan deskriptif, COVID-19 di ringan. yang merawat pasien cross- rumah sakit tersier COVID-19 dari sectional di Wuhan, Cina. perspektif altruistik

Babore, Menguji respon tenaga Studi 595 orang tenaga - Tingkat stres pada wanita et al., kesehatan di Italia kuantitatif kesehatan di Italia (mean =19,56; SD = 7,06) 2020 terkait stres yang cross- lebih tinggi daripada pria dipersepsikan dan sectional (mean $=15,38 ; \mathrm{SD}=6,65)$. strategi koping dalam - Memiliki anak berasosiasi menghadapi pandemi dengan rendahnya tingkat COVID-19 stres $[\mathrm{F}(1,593)=10,798 ; \mathrm{p}$ $=.001]$.

\begin{tabular}{llrllll}
\hline Juan, et & Memantau & distres & Studi & 456 & orang staf & $43,2 \%$ partisipan \\
al., 2020 & psikologis pada staf & kuantitatif & medis dari empat & menunjukkan adanya distres \\
& rumah & sakit dan & cross- & rumah & sakit & psikologis dengan gejala yang \\
& menguji & hubungan & sectional & nasional COVID-19 & ditunjukkan yaitu gejala \\
& antara & distres & & di Chongqing, Cina. & kecemasan, depresi, obsessive \\
& psikologis & dengan & & & & compulsive disorder (OCD), \\
& kemungkinan penyebab & & & & dan somatisasi.
\end{tabular}
stres selama epidemi COVID-19.

Tabel 2. Rangkuman Faktor-faktor yang Berkaitan dengan Stres pada Tenaga Kesehatan

Penulis \& tahun

Dobson, et al., $2020 \quad$ Burnout; riwayat psikiatri yang dimiliki; profesi; dan resiliensi.

Alizadeh, et al., 2020 Faktor yang berkaitan dengan stres terbagi menjadi dua kategori:

- Kategori (1): tuntutan organisasi (sifat penyakit; tuntutan organisasi: tuntutan sosial).

- Kategori (2): sumber daya pendukung (dukungan personal; dukungan sosial).

\begin{tabular}{ll}
\hline Wang et al., 2020 & $\begin{array}{l}\text { Profesi; status perkawinan; banyaknya hari yang dihabiskan untuk merawat } \\
\text { pasien COVID-19 dan menjadi anggota rescue staff. }\end{array}$ \\
\hline Babore, et al., 2020 & Gender; strategi koping; dan merawat pasien COVID-19.
\end{tabular}

\begin{tabular}{ll}
\hline \multicolumn{1}{c}{ Penulis \& tahun } & \multicolumn{1}{c}{ Hasil Penelitian } \\
\hline Juan, et al., 2020 & Gender; tingginya beban kerja; ketidaknyamanan yang muncul akibat \\
& pemakaian APD; belum adanya prosedur pengobatan yang tetap untuk penyakit \\
& ini; keterbatasan diri karena karantina; situasi kerja yang repetitif; rasa takut \\
& untuk pergi bekerja; rasa takut tertular; rasa takut akan kematian; dan sulit \\
& tidur.
\end{tabular}


Pembahasan

$\begin{array}{lcr}\text { Situasi } & \text { pandemi } & \text { COVID-19 } \\ \text { menyebabkan } & \text { tenaga } & \text { kesehatan } \\ \text { memperoleh } & \text { pengalaman } & \text { psikologis } \\ \text { tertentu seperti yang dijelaskan dalam }\end{array}$
penelitian Liu, et al. (2020). Pertama, tenaga kesehatan merasa memiliki peran yang krusial dan berusaha yang terbaik dalam menangani pandemi. Kedua, tenaga kesehatan menghadapi tantangan pekerjaan, seperti berhadapan dengan situasi baru, kelelahan karena beban kerja dan APD yang berat, rasa takut tertular dan menularkan, rasa tidak mampu untuk menolong pasien, dan menjaga hubungan dengan orang lain di situasi pandemi. Ketiga, tantangan untuk resilien, bergantung pada dukungan sosial dan strategi koping.

Tantangan pekerjaan yang berat dapat menimbulkan masalah psikologis pada tenaga kesehatan, salah satunya stres. Berdasarkan tinjauan literatur di atas, tenaga kesehatan dapat mengalami stres psikologis saat menangani pandemi COVID-19 dengan tingkat ringan (Wang, et al., 2020), sedang, hingga berat (Dobson, et al., 2020). Stres pada tenaga kesehatan ditunjukkan dengan adanya gejala-gejala psikologis, seperti gejala depresi, kecemasan, PTSD (Dobson, et al., 2020); OCD, dan somatisasi (Juan, et al., 2020).
Penelitian pertama dilakukan oleh Dobson, et al. (2020) terhadap 320 orang tenaga kesehatan di rumah sakit tersier di Melbourne, Australia yang terdiri dari 99 dokter $(31 \%, 58$ dokter senior, 41 dokter junior), 84 perawat (26\%), 105 praktisi kesehatan pendukung (33\%), dan tenaga non klinis (9\%). Mayoritas partisipan adalah wanita (78\%). 241 partisipan (75\%) memiliki pengalaman kerja lebih dari lima tahun dan 121 partisipan (39\%) merupakan front-line workers. Dokter dan perawat lebih sering berhubungan langsung pasien COVID-19. 98 partisipan (31\%) melaporkan riwayat psikiatri yang dimiliki di mana dokter senior paling sedikit melaporkan riwayat psikiatri dibandingkan yang lain.

Dobson, et al. (2020) dalam penelitiannya menjelaskan faktor-faktor yang berkaitan dengan stres sebagai berikut: (1) Burnout berasosiasi dengan tingginya gejala kecemasan, depresi, dan PTSD; (2) Resiliensi berasosiasi dengan rendahnya tingkat kecemasan, depresi, dan PTSD; (3) Profesi dokter senior yang menunjukkan tingkat stres yang lebih rendah dibandingkan profesi lain; (4) Riwayat psikiatri individu berasosiasi dengan tingginya gejala kecemasan, depresi, PTSD, dan burnout.

Penelitian kedua dilakukan oleh Alizadeh, et al. (2020) terhadap 18 orang 
tenaga kesehatan yang menangani pasien COVID-19 di rumah sakit rujukan di Iran yang terdiri dari 10 wanita dan 8 pria. Partisipan berusia 24 - 42 tahun, terdiri dari 6 dokter dan 12 perawat, serta 13 menikah dan 5 belum menikah. Dari hasil wawancara terhadap partisipan, Alizadeh, et al. (2020) membagi faktor-faktor yang berkaitan dengan stres ke dalam dua kategori. Kategori pertama terbagi menjadi tiga subkategori, yaitu: (1) Stres karena sifat penyakit yang terdiri dari tingginya beban kerja; ketidaknyamanan yang muncul akibat pemakaian APD; belum adanya prosedur pengobatan yang tetap untuk penyakit ini; keterbatasan diri karena karantina; situasi kerja yang repetitif; rasa takut untuk pergi bekerja; rasa takut tertular; rasa takut akan kematian; dan sulit tidur; (2) Stres karena tuntutan organisasi: ketidakadilan di tempat kerja; masalah ekonomi; masalah manajemen; kekurangan tenaga dan peralatan; serta defisiensi dan kelelahan pada sumber daya manusia (SDM). (3) Stres karena tuntutan sosial: adanya stigma bahwa tenaga kesehatan dapat menularkan virus; media cenderung melebih-lebihkan isu; kurangnya perhatian masyarakat terhadap kesehatan dan karantina.

Lebih lanjut, Alizadeh, et al. (2020) menjelaskan kategori kedua yang terbagi menjadi dua subkategori. Subkategori pertama, dukungan personal terdiri dari kemampuan koping yang berorientasi pada masalah; compassion satisfaction (kepedulian, komitmen, dan kepuasan terhadap perkembangan kesehatan pasien); spiritualitas; kepribadian; dan dukungan sosial. Subkategori kedua, dukungan sosial terdiri dari kerja tim; dukungan dari teman; dukungan dari keluarga; dan penghargaan terhadap perawat.

Penelitian ketiga dilakukan oleh Wang, et al. (2020) terhadap 1208 orang tenaga kesehatan yang menangani pasien COVID-19 di rumah sakit tersier di Wuhan, Cina, yang terdiri dari 118 pria dan 1090 wanita dengan rata-rata usia 30,7 tahun dan rata-rata lama bekerja 7,8 tahun. $86,1 \%$ partisipan merupakan perawat, sedangkan sisanya dokter, apoteker, teknisi laboratorium, dan radiolog. $60 \%$ partisipan sudah menikah dan 50,2\% sudah memiliki anak. 84,7\% partisipan merupakan frontline workers. Berdasarkan analisis terhadap demografi tersebut, tingkat stres partisipan lebih tinggi pada: (1) Perawat dibandingkan dokter; (2) Partisipan yang sudah menikah dibandingkan yang belum menikah; dan (3) Tenaga kesehatan frontline (rescue staff) dibandingkan tenaga kesehatan provincial. 
Penelitian keempat dilakukan oleh Babore, et al. (2020) terhadap 595 orang tenaga kesehatan di Italia dengan rata-rata usia 40,69 tahun dan mayoritas wanita $(80,3 \%)$ yang terdiri dari $44 \%$ perawat, $29,2 \%$ dokter, dan $14,1 \%$ tenaga teknis (radiolog, petugas lab, dsb). 48,7\% partisipan berhadapan langsung dengan pasien COVID-19. 75,3\% partisipan sudah menikah dan $51 \%$ sudah memiliki anak. Dari segi sosioekonomi, rata-rata penghasilan partisipan di atas 28.000 euro per tahun.

Lebih lanjut Babore, et al. (2020) dalam penelitiannya menjelaskan faktorfaktor yang berkaitan dengan stres, di antaranya gender, keberadaan anak, strategi koping, dan merawat pasien COVID-19. Pertama, tingkat stres pada wanita lebih tinggi daripada pria. Kedua, tingkat stres pada partisipan yang memiliki anak lebih rendah. Ketiga, ada lima aspek strategi koping yang diuji, namun aspek pemecahan masalah dan "menganut agama" tidak termasuk karena hasil statistiknya tidak signifikan. Aspek strategi koping yang berkaitan dengan tingginya tingkat stres adalah rendahnya sikap positif, tingginya dukungan sosial, tingginya strategi penghindaran. Kemudian faktor keempat, partisipan yang merawat pasien COVID-19 menunjukkan tingkat stres yang lebih tinggi.
Penelitian kelima dilakukan oleh Juan, et al. (2020) 456 orang staf medis dari empat rumah sakit nasional COVID19 di Chongqing, Cina, yang terdiri dari $29,4 \%$ pria; $68,1 \%$ tingkat pendidikan sarjana atau lebih tinggi; 53,1\% menikah atau tinggal bersama dengan pasangan; $57,2 \%$ perawat; $42,8 \%$ dokter; dan $21,2 \%$ berkontak langsung dengan pasien COVID-19. Lebih lanjut Juan et al. (2020) menjelaskan bahwa gender berasosiasi dengan tingginya distres psikologis, khususnya pada wanita. Selain itu, ada faktor-faktor yang berkaitan dengan distres psikologis saat pandemi COVID19. Pertama, faktor yang berkaitan dengan respon psikologis terdiri dari keengganan untuk masuk kerja atau ingin mengundurkan diri; takut pulang ke rumah karena berpotensi menularkan penyakit ke keluarga; ketidakpastian modifikasi infeksi dan prosedur kontrol; dan dukungan sosial. Kedua, faktor yang berkaitan dengan kecemasan, OCS, dan somatisasi terdiri dari keengganan untuk masuk kerja atau ingin mengundurkan diri; takut pulang ke rumah karena berpotensi menularkan penyakit ke keluarga. Kemudian yang ketiga, faktor yang berkaitan dengan depresi terdiri dari stigma dan penolakan oleh orang-orang di sekitar; enggan untuk masuk kerja atau 
ingin mengundurkan diri; ketidakpastian modifikasi infeksi dan prosedur kontrol.

Berdasarkan kelima penelitian di atas, ada banyak faktor yang berkaitan dengan stres, di antaranya: (1) Sosiodemografis (gender, status perkawinan, profesi, keberadaan anak, riwayat psikiatri yang dimiliki); (2) Kondisi personal (strategi koping, resiliensi, compassion satisfaction, spiritualitas, kepribadian); (3) Tuntutan organisasi (terlibat langsung dalam merawat pasien COVID-19, tingginya beban kerja, burnout, ketidaknyamanan memakai APD, belum adanya prosedur pengobatan yang tetap, kekurangan tenaga dan peralatan, keterbatasan diri karena karantina, situasi kerja yang repetitif, enggan untuk masuk kerja atau ingin mengundurkan diri, rasa takut untuk pergi bekerja, rasa takut tertular dan menularkan, rasa takut akan kematian, dan sulit tidur, ketidakadilan di tempat kerja, masalah ekonomi, dan masalah manajemen); serta (4) Dukungan sosial (kerja tim, dukungan dari teman, dukungan dari keluarga, penghargaan terhadap perawat, adanya stigma bahwa tenaga kesehatan dapat menularkan virus, media cenderung melebih-lebihkan isu, kurangnya perhatian masyarakat terhadap kesehatan dan karantina).

\section{PENUTUP}

Berdasarkan kelima penelitian di atas, tenaga kesehatan menunjukkan tingkat stres ringan hingga berat saat menghadapi pandemi COVID-19. Hal ini disebabkan oleh adanya faktor sosiodemografis, kondisi personal, tuntutan organisasi, dan dukungan sosial.

Studi ini memiliki keterbatasan yaitu penelitian mengenai stres pada tenaga kesehatan saat menghadapi pandemi COVID-19 di Indonesia belum banyak dilakukan sehingga faktor-faktor yang dibahas pada lima penelitian di atas, khususnya faktor sosiodemografis, belum tentu relevan dengan situasi di Indonesia. Peneliti selanjutnya diharapkan dapat mengakses lebih banyak mesin pencarian untuk memperoleh lebih banyak jurnal penelitian terkait faktor-faktor yang berkaitan dengan stres pada tenaga kesehatan saat menghadapi pandemi COVID-19.

\section{DAFTAR PUSTAKA}

Alizadeh, A., Khankeh, H. R., Barati, M., Ahmadi, Y., Hadian, A., \& Azizi, M. (2020). Psychological Distress among Iranian Health-care Providers Exposed to Coronavirus Disease 2019 (COVID-19): A Qualitative Study. Research Square. https://doi.org/10.1177/103985622 0965045. 
Babore, A., Lombardi, L., Viveconti, M. L., Pignataro, S., Marino, V., Crudele, M., . . . Trumello, C. 2020. Psychological Effects of the COVID-19 pandemic: Perceived Stress and Coping Strategies among Healthcare Professionals. Psychiatry Research, 293. https://doi.org/10.1016/j.psychres. 2020.113366.

Chen, B., Li, Q.-X., Zhang, H., Zhu, J.-y., Yang, X., Wu, Y.-h., ... Chen, Z.t. 2020. The Psychological Impact of COVID-19 Outbreak on Medical Staff and The General Public. Current Psychology. https://doi.org/10.1007/s12144020-01109-0.

da Silva, F. T., \& Neto, M. R. 2020. Psychiatric Symptomatology associated with Depression, Anxiety, Distress, and Insomnia in Health Professionals Working in Patients Affected by COVID-19: A Systematic Review with Metaanalysis. Progress in NeuroPsychopharmacology and Biological Psychiatry, 104. https://doi.org/10.1016/j.pnpbp.20 20.110057.

Dobson, H., Malpas, C. B., Burrell, A. J., Gurvich, C., Chen, L., Kulkarni, J., \& Winton-Brown, T. 2020. Burnout and Psychological Distress Amongst Australian Healthcare Workers during the COVID-19 pandemic. Australasian Psychiatry, 1-5. https://doi.org/10.1177/103985622 0965045.

Hendriani, W. 2019. Resiliensi Psikologis Sebuah Pengantar. Jakarta Timur: Prenadamedia Group.
Juan, Y., Yuanyuan, C., Qiuxiang, Y., Cong, L., Xiaofeng, L., Yundong, Z., . . . Yujie, L. 2020. Psychological Distress Surveillance and Related Impact Analysis of Hospital Staff during The COVID-19 Epidemic in Chongqing, China. Comprehensive Psychiatry, 103. https://doi.org/10.1016/j.comppsyc h.2020.152198.

Liu, Q., Haase, J. E., Guo, Q., Wang, X. Q., Liu, S., Xia, L., ... Yang, B. $X$. 2020. The Experiences of Health-care Providers during The COVID-19 Crisis in China: A Qualitative Study. Lancet Global Health, $\quad 8, \quad 790-798$. https://doi.org/10.1016/S2214109X(20)30204-7.

https://doi.org/10.1016/S2214109X(20)30204-7.

Muller, A. E., Hafstad, E. V., Himmels, J. W., Smedslund, G., Flottorp, S., Stroobants, S., . . . Vist, G. E. 2020. The Mental Health Impact of the COVID-19 Pandemic on Healthcare Workers, and Interventions to Help Them: A Rapid Systematic Review. Psychiatry Research, 293. https://doi.org/10.1016/j.psychres. 2020.113441

Rehman, U., Shahnawaz, M. G., Khan, N. H., Kharshiing, K. D., Khursheed, M., Gupta, K., . . . Uniyal, R. 2020. Depression, Anxiety and Stress among Indians in Time of COVID-19 Lockdown. Community Mental Health Journal. https://doi.org/10.1007/s10597020-00664-x. 
Wang, H., Liu, Y., Hu, K., Zhang, M., Du, M., Huang, H., \& Yue, X. 2020. Healthcare Workers' Stress when Caring for COVID-19 Patiens: An Altruistic Perspective. Nursing Ethics, 27(7), 1490-1500. https://doi.org/10.1177/096973302 0934146.

WHO, W. H. (2020, November 03). WHO Coronavirus Disease (COVID-19) Dashboard. Retrieved from World Health Organization: https://covid19.who.int/. 